\title{
Soil-Erosion Research on The Determination of the Degree of Potential Hazards of Mining-Brown Stepped Soils of the Quba-Khachmas Zone of Azebajan
}

\author{
Rae ZH Aliyev* \\ Institute of Erosion and Irrigation NAS of Azerbaijan, Azerbaijan
}

Submission: November 14, 2017; Published: December 04, 2017

*Corresponding author: Rae ZH Aliyev, Institute of Erosion and Irrigation NAS of Azerbaijan, Baku, Azerbaijan, Email: zakirakademik@mail.ru

\begin{abstract}
On the plots under sowing of field crops traits for which you can define the degree of soil erosion are projective cover and height plants. Enthusiastically steepness of slopes the possibility of using cultivated crops as indicators of soil erosion is reduced. The degree of soil erosion of natural grassland can be estimated based on existing dependencies between the grass plants and extent of soil erosion. Pretty strong erodirovannost soils of sloping meadows can be recognized for environmental regimes of vegetation habitats.
\end{abstract}

Keywords : Erodirovannyj; Humus; Srednesmytyj; Bio-Climatic; Plotnodernovye; Cenozy; Stepped

\section{Introduction}

In the context of Azerbaijan the process of erosion has become a large development, calling for a washout, erosion and deflation, etc. types of unwanted consequences of destroying the aggregate properties of soils. It is expressed most clearly in the soils, cultivated in rainfed conditions in the example object. The aim of achieving completeness solvable problems of land management, erosion or potentially dangerous erosion should be deeply know every plot of land in the region, its features that can influence the choice of crops in the territory of the rajoniruemoj, the method of irrigation or private receptions machinery. Therefore, it is possible only as a result of deep surveys the territory. We should also recognize that the stronger are affected by erosion of the soil, the more they differ from their nesmytyh analogues on chemical, granulometric composition and physico-chemical properties, water, air and thermal regimes of biogenic and other indicators, which together affect their fertility and erosion resistance [1].

Table 1: Diagnostic indicators of varying degrees of erosion the mountain-ostepenjonnyh Brown soils.

\begin{tabular}{|c|c|c|c|c|c|c|}
\hline \multirow{2}{*}{$\begin{array}{c}\text { The degree of erosion and } \\
\text { its designation }\end{array}$} & \multirow{2}{*}{$\begin{array}{c}\text { Power horizons } \\
\mathbf{a}+\mathbf{b}\end{array}$} & \multicolumn{3}{|c|}{ Gross margin, $t / h a$} & \multirow{2}{*}{$\begin{array}{l}\text { Vodoprochnye aggregates } \\
\text { more than } 1 \mathrm{~mm}\end{array}$} & \multirow{2}{*}{ Yield kg/ha } \\
\hline & & Humus & Nitrogen & Phosphorus & & \\
\hline Not eroded & 75 & 168 & 10.5 & 6.4 & 52 & 28.5 \\
\hline Very little eroded & 70 & 156 & 8.8 & 5.8 & 48 & 26.2 \\
\hline Weakly eroded & 60 & 135 & 7.6 & 5.0 & 42 & 22.3 \\
\hline Moderately eroded & 45 & 108 & 5.6 & 3.2 & 30 & 15.8 \\
\hline Heavily eroded & 30 & 65 & 3.8 & 2.3 & 18 & 9.8 \\
\hline Very heavily eroded & Less than 15 & 32 & 1.9 & 1.2 & 8 & 6.4 \\
\hline
\end{tabular}

\section{The Moves and Discuss the Results of the Study}

As a result, undertaken under the direction of Prof. B.H. Aliyev [2] research jointly with experts of the Polish Institute of technology revealed that soil erosion is reduced humus content. However, the margin when 0-50 cm layer in nesmytyh mining and ostepenjonnyh Brown soils is $168 \mathrm{t} / \mathrm{ha}$, in a very slabosmytyh-156t/ ha, slobosmytyh-135 t/ha, srednesmytyh-108 t/ha, silnosmytyh-65 t/ha, and in very silnosmytyh-32 t/ha. In eroded soils not only decreases the total humus content, but also decreases the contents of mobile forms of humic acids. According to the author, these changes are the stronger, the more are affected by erosion of the soil. It is believed that the decrease of humic acids leads to lower fertility, conservation of soil resistance to deterioration. This same decline, in General, proportional to the reduction of nitrogen in the soil. Shortage of available forms of nitrogen is one of the important reasons for the decline of fertility of eroded soils. 


\section{Global Journal of Otolaryngology}

Regularity also reveals decreasing r20 in moderate washed out soils by $30 \%$ and silnosmytyh-more $50 \%$. Reduction of organic phosphates and phosphorus forms insoluble increase leads to deterioration of phosphorus nutrition of plants. In eroded soils are often reduced content of potassium. Thus, its agrochemical characterization of soil washed away are substantially different from unwashed. Hence arises the need for differentiated fertilization in soil with varying degrees of erosion. Results of laboratory studies found that eroded soils differ significantly from not eroded on physical properties. In the eroded soils decreases the content of waterproof structural aggregates. And so, if in the upper horizon of mountain-unwashed Brown step-down soil vodoprochnyh content of the aggregates is $52 \%$ very slabosmytyh- $48 \%$, slabosmytyh- $42 \%$, srednesmytyh-30\%, strongly washed $18 \%$, and in very silnosmytyh- $8 \%$. The number of units of less than $0.25 \mathrm{~mm}$ increments (Table 1).

Not eroded soils are distinguished from eroded visible differentiation of soil profile and greater capacity. Well allocated arable and 2 layers. In the past appears gray-Brown shade effect of alluvion horizon. Subsurface layer is visibly detectable seal and meet the selection of carbonates. Structure of silt-clotted, and Virgin soil-clotted well expressed. The degree of erosion for each soil type is set, depending on which part of the soil profile washed away or deformed horizon from which topsoil is emerging, what is the average percentage yield compared to harvest on nejerodirovannyh soils, and the steepness of slope in degrees. The degree of erosion of soil also depends on the shape of the slope, its length and exposure, the correctness of management, anti-erosion of sustainability, which includes a variety of mechanical, chemical and physical properties. Therefore, on the slopes of the same slope soils can be one, but different subtype of erosion.

The average harvest is a very important indicator in determining the degree of erosion. In the field soil fertility was determined visually by morphological hallmark of a soil profile and as plants on this site. From the data table 1 . It can be seen that as the degree of erosion decreased the power of the horizon $a+b$ and reserve of humus within certain limits. It should be noted that the supply of humus (in tones) is calculated taking into account the nitrogen and

Table 2: Distribution of arable land on the steepness of the slopes and soil erosion administrative areas of the north-eastern part of the Greater Caucasus.

\begin{tabular}{|c|c|c|c|c|c|c|}
\hline \multirow{3}{*}{$\begin{array}{l}\text { Control } \\
\text { areas }\end{array}$} & \multirow{3}{*}{$\begin{array}{c}\text { Total area } \\
\text { HA }\end{array}$} & \multicolumn{3}{|c|}{ The steepness of the slopes } & \multicolumn{2}{|c|}{ Eroded from the entire arable land } \\
\hline & & \multirow[b]{2}{*}{ Cooler 10, HA/\% } & \multicolumn{2}{|c|}{ Including steeper } & \multirow[b]{2}{*}{$\begin{array}{l}\text { Total hectares/ } \\
\text { percent }\end{array}$} & \multirow[b]{2}{*}{$\begin{array}{c}\text { Including a strong } \\
\text { and very badly- } \\
\text { eroded HA/\% }\end{array}$} \\
\hline & & & 50, HA/\% & $80 \mathrm{HA} /, \%$ & & \\
\hline Cuba & 20402 & 1502873.7 & 1038550.9 & 289814.2 & 1346566.0 & 284513.9 \\
\hline Kusar & 31586 & 2348574.4 & 1914760.6 & 46.2514 .6 & 2206669.9 & 433313.7 \\
\hline Davaci & 19421 & 1541879.3 & 1169560.2 & 342017.6 & 1482976.4 & 312716.1 \\
\hline Siyazan & 10767 & 970890.2 & 714263.3 & 213819.9 & 870880.9 & 194218.0 \\
\hline Khachmaz branch & 39624 & 1422535.9 & 3270.8 & - & 1189030.0 & 5381.4 \\
\hline Total & 121800 & 7786463.9 & 4866940.0 & 1308110.7 & 7095858.0 & 1278510.5 \\
\hline
\end{tabular}

phosphorus. In addition, data on crops as listed in the classification of eroded soils, somewhat understated. Our nursery (2008-2010) studies have shown that the harvest of winter wheat at very little eroded mountain-Brown soils in the rolling average is reduced to $10 \%$ for medium-up to $25 \%$ of eroded, and the strong eroded h-up to $75 \%$ compared with crops on soils which nejerodirovannyh Institute for land reclamation and grassland of the NDP. To achieve this goal, the potential dangers of erosion mapping based on local characteristics of soils, we adopted the following grouped by degree of soil erosion.

Jerodirovannost land, which is set depending on the steepness and slope exposure, the depth of local bases, erosion degree of erosion, the nature of the underlying rocks, belonging to one or other agricultural lands. Graduation steepness of slopes for arable land were taken as follows: $0-1 ; 1-3 ; 3-5 ; 5-8 ; 8-12$ and more than 12. Other land: $0-1 ; 1-3 ; 3-5 ; 5-8 ; 8-12 ; 121-20 ; 20-30 ; 30-45$ and more. On the slopes following graduation be taken exposure: North, Northeast, Northwest, East, West, South West, South East and the erosion: $0-20$; 20-50; 50-100; 100-150; 150-200; 200-3004 300$400 ; 400-500 ; 500-600 ; 600-800 ; 800-1000 \mathrm{~m}$ and more. According to the degree of erosion of different categories of eroded land kept as soil one degree of erosion and their complexes.

Also take into account the nature of the underlying rocks and their density. For each of the selected groups and categories of eroded land have been given recommendations on their use and application of counter-erosion activities. As the above selection basis relied eroded land are soil maps that reflect all the contours of eroded soils and farmland. While used and supporting special cards steepness, exposure, slopes and depth of local bases of erosion. In recent years there has been significant growth in the areas of eroded soils that required for thorough research and allocation of eroded land, which was not previously considered. Consequently, the question arises of the diagnostic study of indicators for measuring the degree of erosion of soil. Sometimes use indicators that determine risk of erosion. and approved the results of long-term researches of experts of South. Where depth graduation local bases were taken following 
For example, in some cases, assessment of erosion of arable soil set based on the data distribution of arable land on the slope. Of course, the steeper slopes, so all things being equal on them increases the degree of soil erosion. However, these are not always equal terms, so the soil more steep slopes may be less inclined than are affected by erosion (Table 2) as can be seen from the table, in the north-eastern part of the Greater Caucasus arable land on terrain conditions are more favourable than the South-East or South of the Greater Caucasus. Therefore, the soil cover is relatively less eroded. This is largely due to the relatively higher conservation soil stability, favourable rainfall and pochvozashhitnoj role of vegetation. Favourable rainfall and soil protection role of vegetation.

Soil erosion studies in Azerbaijan showed that factor exposure slopes more often affects distribution of eroded soils than the steepness of slopes. So when surveyed in the forest zone of GornoBrown soil stepped on one of the areas with a slope of $15-20$ on the southern slope of the strongly eroded soil, were found on the slopes of the Northern exposure with a slope of 15-200 -weakly eroded. It was found a great influence on the distribution of soil exposure. So on the slopes of the Northern exposure when slopes 8-120 GornoBrown stepped soils wash is $19.2 \mathrm{~m} / \mathrm{ha}$, while similar conditions southern exposure reaches soil washout $45.8 \mathrm{~m} / \mathrm{ha}$. If on the slopes of the southern exposure medium and silnojerodirovannye soils occupy $41.2 \%$ of the area, on the slopes of Northern exposure in similar circumstances-just $9.8 \%$.

Square units of each category and groups of eroded land have been calculated, taking into account the genetic soil types. As a result, became possible be explication of eroded land of Azerbaijan. In explicating contains data on the number of each type of eroded soils varying degrees of erosion on slopes or another surface, consisting of various agricultural land. Further synthesis of erosion of land is to bring them into the Republican maps, where, with the aim of zoning activities rise shows the dependence of the soil cover. To highlight eroded territories the following gradation of the basis for the allocation of eroded land. Based on the data mapping of eroded soils, as well as the cameral works compiled map of soil erosion of the Azerbaijan Republic with the following application:

\section{Area lack of Erosion:}

-do not subject to erosion under forests;

-not prone to soil erosion, natural senekosom and occupied marsh vegetation;

-soil, confined to such lands, as deposits, gardens.

\subsubsection{Area Subject to Erosion:}

Depending on the amount of soil with varying degrees of destruction of genetic horizons lands are divided into five groups:

a) Very little eroded land: where slabosmytye a difference constitute no more than $10 \%$ and silnosmytye soils are not available.

b) Weakly eroded land: where the total area of eroded differences is $25 \%$. Area slabosmytyh - $20 \%$ srednesmytyh soilnot more than $5 \%$, and silnosmytye soils are not available.

c) Middling soil eroded: Only up to $50 \%$ of eroded soils. Square of contours with medium soils jerodirovannymi reaches $30 \%$, slightly eroded-to $15 \%$ and silnojerodirovannyh-up to $5 \%$ and very silnojerodirovannye is $10 \%$.

d) Heavily eroded soils: Jerodirovannost soils is about $75 \%$ of the total area. Of these, silnojerodirovannye- $40 \%$, srednejerodirovannye-to 25\%, and very silnojerodirovannye-10\%.

e) Highly silnojerodirovannye soils: Eroded area accounted for more than 75\%. Very silnojerodirovannye-bolee $50 \%$, medium, silnojerodirovannye-more than $25 \%$.

Given our experience, we fully share the views of F.s. Kozmenko, g.a. Presnyakova, S.s., Sobolev K. Alekperova, m.n. Zaslavsky that coloring the top layer of soil can be taken as the rate of erosion.

f) In not washed-colour dark brown: humus content-5\%, nitrogen-0.30\%, fosfora_0, 22\%, capacity-35 mjekv absorption on $100 \mathrm{~g}$ of soil, structural units vodoprochnost-mm over $1 \mathrm{~km}$ with $52 \%$.

g) Very poorly washed away: Horizon and washed not more than $20 \%$, the color of the soil a little different from nesmytyh (dark brown). Humus content in the upper horizon is $4.6 \%$, nitrogen- $0.28 \%$, phosphorus- $0.19 \%$ absorption capacity- 32.5 mjekv on $100 \mathrm{~g}$ of soil, the number of vodoprochnyh units over $1 \mathrm{~mm} \mathrm{48 \%}$. Yields below $10 \%$ than that of nesmytyh.

h) Poorly washed away: Horizon and from 20 to $50 \%$ washed soil color Brown, humus content- $4 \%$, nitrogen- $0.24 \%$, phosphorus- $0.16 \%$, absorption capacity-CIECA 28.8 to $100 \mathrm{~g}$ of soil, the number of vodoprochnyh units-48\%. Yields below (from 10 up to $25 \%$ ) than nesmytyh soils.

i) Medium washed away: Horizon and washed away completely. soil color is lightbrown, humus content-2.8\%-0.18\% nitrogen, phosphorus- $0.10 \%$, absorption capacity is 23.8 CIECA on $100 \mathrm{~g}$ of soil, vodoprochnye units-30\% productivity below from $25-50 \%$ than that of nesmytyh.

j) Heavily washed away: Wash off the horizon in1, the color of the soil-zheltovatyj with brownish tinge. The content of humus-1.2\%-0.08\% nitrogen, phosphorus- $0.05 \%$, absorption capacity is 14.5 to $100 \mathrm{~g}$ of soil CIECA, vodoprochnyh units-18\%, yield-from 50 to $75 \%$ (Table 2).

k) Very heavily washed away: Rinse off completely the soil layer on the surface of exposed, loose and hard woods [3].

General provisions for the classification of eroded soils are the following: selection of diagnostic indicators to determine degrees of erosion of soil, suitable quantity allocated to degrees of erosion soil standards to ascertain their degree of erosion For. mining-Brown soil erosion degree stepped is invited to determine 


\section{Global Journal of Otolaryngology}

to reduce genetic horizons and reduce the content of humus in the horizons of $\mathrm{a}+\mathrm{b}$. very weak jerodirovannym it is recommended to classify the soil in which the compared with non-eroded the reduction and horizon to $20 \%$ and up to $10 \%$ of humus, to weakly jerodirovannym respectively $10-25 \%$ to srednejerodirovannym $\%$, 25-50-silnojerodirovannym-50-75\%. these graduation offered, taking into account the variation in the the humus content in soil and nesmytyh laboratory error definitions. Determination of the degree of erosion of soils based on quantitative change in humus content in the surface layer of soil-is an accurate and objective method that can be used in exposed soil mapping mining-Brown soil and stepped close to him on the genesis of soils [4] (Table 3).

Table 3: The degree of soil erosion.

\begin{tabular}{|c|c|c|c|}
\hline The degree of erosion & Genetic horizons Smytost, $\%$ & Reducing the stock of humus, $\%$ & $<10$ \\
\hline Very little eroded & (A) up to 20 & $10-25$ & $25-50$ \\
\hline Weakly eroded & (A) $20-50$ & $50-75$ & Slightly below average \\
\hline Moderately eroded & (A) fully & $>75$ & Average \\
\hline Heavily eroded & In about 50 & Izrezhennoe & Very bad \\
\hline
\end{tabular}

Natural hayfields and pastures, is constantly covered with vegetation, considered the most effective form of conservation lands. However, due to the deprivation of the protective cover on the slopes increased run-off of soil, which contributes to erosive process. In their geographical distribution of erosion on pasture appear in a certain area of subordination, which is confined to certain areas and bioklimaticheskim is a product of the evolution of the bio-climatic Wednesday [5]. Depending on the degree of development of erosive process, the nature of vegetation and soil generic breeds, each selected type of erosion is divided into subtypes and variants. Grouping of eroded soils of the Republic covers the main natural-landscape zones, taking into account the landscape and climatic conditions of each zone. Highland climate differs harsh long protracted winter snow and frost. Summers are short and cool.

The average annual temperature does not exceed $3.2-4.10$, and the coldest month (January) range from $-4.6-7.90 \mathrm{c}$, the temperature of the warmest month (July) is low, ranging from $12.9-13.70 \mathrm{c}$; the sum of temperatures above 100 very low and average does not exceed 800-600. Duration of the frost-free period 1-2 months, vegetation period lasts 90-120 days. Average number of approximately $610-1210 \mathrm{~mm}$, moisture ratio $1.52-1.22$, total solar radiation (annual) changes within $144-156 \mathrm{kcal} / \mathrm{cm}^{2}$. For the climatic indicators of the whole territory of the Highlands refers to wet $(\mathrm{MD}<0.45)$ and cold $(\Sigma \mathrm{T}>800)$ climatic type. Floristic composition of the vegetation is extremely heterogeneous and varies with altitude.

In the most elevated part of the vegetation canopy cover not provided-groups skalnoosypej (lichens, algae, etc.) For the Alpine meadows are typical plotnodernovye meadows with zlakovooskovymi components. Subalpine meadows are presented cenozami cereals, grasses, thickets of rhododendron, and in relatively dry parts of the Meadow-steppe communities. The main soil types are: mountain-meadow, mountain-forest-meadow and mountain-meadow-steppe. Agricultural production is weak, the zone largely occupied by wealthy summer pastures and mowed lands and are the basis for the development of transhumance (sheep) and fodder production [6].

Alpine and subalpine meadows, the main area which is occupied by pastures, soil erosion is the factor, which is closely linked areas. Stripped of protective vegetation, soil sloping land can't absorb the snow and rain water. This leads to an obsession with surface runoff which enhances ripple rivers. As a result of violations of the hydrological regime of the territory, which is due mainly to the removal of forest and grassy vegetation, knocking in the rivers of the mountain areas often seen very strong fluctuations in the volume of river flow. A large loss of water runoff regime of rivers worsens as snow, and especially power snegodozhdevogo. This, in its turn, reduces irrigation capacity of rivers on the territory of the foothill Plains, necessitates the use of large irrigation and reclamation work [7].

Erosive processes that resulted from the degradation of the vegetation of pasture, contributing to a sharp drop in the productivity of pastures. Therefore, soil erosion and deterioration in the quality of grass-processes are closely linked. A well-developed natural grass cover markedly increases the resistance of soils and erosion of the leachate may run off. Development processes of erosion affects not only the quantitative indicators of pasture plants, but also leads to a restructuring of phytocoenosis [8]. From the total area of 2402.3 hectares of mountain pastures over 1985, 8 thousand hectares or $82.7 \%$ are prone to erosion. Pastures depending on subband and exposure of the slope wash soil varies ot50 to $125 \mathrm{~m}^{3} / \mathrm{HA}$. From these studies derives great economical importance is the study of pasture erosion in mountainous areas and the development of techniques to prevent and fight against it.

When developing differential measures for the improvement and rational use of pastures, there is always a need for classification and grouping of grazing land for their quality status. It should be noted, however, that classification pasture erosion has now developed enough [9]. Moreover, even the phenomenon of erosion on pasture do not found a definite place in the common grouping of erosive processes, although the nature of the manifestations 
of pasture erosion is very much different from other types or categories of erosion. On the classification of eroded soils of mountain pastures known works of some author: V.a. Meeting, 1958, D.j. Mihjlova, 1959, Sw Kerimhanova 1972. In these works gives grouping soils grazing on a degree as they are destroyed. In the forms of accelerated erosion caused by human activities, have a lot in common. However, according to and from the reasons caused the manifestation of erosion, these forms have their own characteristics.

The character manifestation of soil erosion of mountain pastures pretty sharply differs from erosion on cultivated hillsides. Erosion processes on the pastures start to develop normally, since damage to the turf. Mountain pasture soil destruction process has no similarities with the formation of gullies and potholes. The length of the pits not always exceeds their width, and availability under lower-powered soil layer waterproof dense rocks brings not on no growth pits deep. Further growth in the size of erosion pits usually occurs through the broken walls, sliding down the slope of sod places preserved woven roots and reminiscent of education in the second stage of its development. Raised near each other erosive pits are often steep walls and expands, incorporate among themselves, forming patches or streaks of eroded soil [10].

Table 4: Classification of pasture erosion on hillsides.

\begin{tabular}{|c|c|c|}
\hline Stage & The degree of & Indicators \\
\hline \multirow{4}{*}{$\begin{array}{c}\text { Vybitost } \\
\text { (tropinchatost) }\end{array}$} & Very weak & $\begin{array}{c}\text { The total area of paths: }<10 \% \\
\text { of the account area }\end{array}$ \\
\cline { 2 - 3 } & Weak & $10-25 \%$ \\
\cline { 2 - 3 } & Average & $25-50 \%$ \\
\cline { 2 - 3 } & Strong & $50-75 \%$ \\
\cline { 2 - 3 } & Very strong & $\neg 75 \%$ \\
\hline
\end{tabular}

As the further destruction of the soil occurs more or less gradual alignment of bugorchatogo through the shedding of microrelief, and under the influence of склонового runoff. This specificity of the appearance of erosion on mountain pastures requires, firstly, providing pasture erosion in independent or category subtype, secondly, development of appropriate soil classification according to the degree of their erosion. Based on long-term observations, taking into account the peculiarities of the destructive processes of soils under the influence of the unrestrained grazing of livestock, it is proposed that the draft classification pasture erosion on erosion degree (Table 4). This includes the sequence of dernennogo deformation process layer. Research indicates the possibility of using cultural vegetation cropland and grass native grasslands in order to clarify the erosive soil survey data.

\section{References}

1. Alekperov K A (1980) Pochvoezionnaya map and land protection. Moscow, Russia.

2. Aliev BH (2005) The problem of desertification in Azerbaijan and ways to solve it. «Ziya-Naji» publishing house, Baku, Azerbaijan.

3. Zaslavsky MN (1969) To the draft classification of soils according to the degree of erosion. Sat «Materials on the methodology of soilerosion mapping of erosion control measures.»

4. Zaslavsky MN (1983) Erosiology, publishing house Higher School.

5. Ibrahimov AA (2001) Mapping of eroded soils on agricultural lands, (on the example of the Dashkesan region of the Azeri SSR.

6. AA Ibrahimov (2000) Agroecological feature of eroded soils of Azerbaijan. Materials on the study of erosion and irrigation and soil conservation in Azerbaijan.

7. Sobelyov SS (1948) The development of erosion processes on the territory of the European part of the USSR and the struggle against them. Publishing House of the USSR Academy of Sciences 1: 1948

8. Sobolev SS (1961) Protection of soils from erosion.

9. Filkov VA (1958) Soil-Erosional zoning of the Kamensk and Rostov regions. Sb. «Soil erosion and struggle with it», Moscow, Russia.

10. Jozefacik A, Jozefacik CZ (1995) Erozya aqroekosystemow. Panstwowa Inspekcya Ochrony Srodowicka. Warszawa: Putawwy as IUNG 168.

\section{Your next submission with Juniper Publishers} will reach you the below assets

- Quality Editorial service

- Swift Peer Review

- Reprints availability

- E-prints Service

- Manuscript Podcast for convenient understanding

- Global attainment for your research

- Manuscript accessibility in different formats

( Pdf, E-pub, Full Text, Audio)

- Unceasing customer service

Track the below URL for one-step submission https://juniperpublishers.com/online-submission.php 